\title{
"The effect of revenue diversification on the firm value and stability of banks: A comparative study of Nigerian and Malaysian banks"
}

\begin{tabular}{|c|c|}
\hline AUTHORS & $\begin{array}{l}\text { Oluwaseyi Olalere (iD) } \\
\text { Md. Aminul Islam (iD) } \\
\text { Marniati } \\
\text { Nurulul Rahmi }\end{array}$ \\
\hline ARTICLE INFO & $\begin{array}{l}\text { Oluwaseyi Olalere, Md. Aminul Islam, Marniati and Nurulul Rahmi (2021). The } \\
\text { effect of revenue diversification on the firm value and stability of banks: A } \\
\text { comparative study of Nigerian and Malaysian banks. Banks and Bank Systems, } \\
\text { 16(3), 141-151. doi:10.21511/bbs.16(3).2021.13 }\end{array}$ \\
\hline DOI & http://dx.doi.org/10.21511/bbs.16(3).2021.13 \\
\hline RELEASED ON & Wednesday, 29 September 2021 \\
\hline RECEIVED ON & Saturday, 20 March 2021 \\
\hline ACCEPTED ON & Friday, 30 July 2021 \\
\hline LICENSE & $\begin{array}{l}(c) E Y \\
\text { This work is licensed under a Creative Commons Attribution } 4.0 \text { International } \\
\text { License }\end{array}$ \\
\hline JOURNAL & "Banks and Bank Systems" \\
\hline ISSN PRINT & $1816-7403$ \\
\hline ISSN ONLINE & $1991-7074$ \\
\hline PUBLISHER & LLC "Consulting Publishing Company "Business Perspectives" \\
\hline FOUNDER & LLC "Consulting Publishing Company "Business Perspectives" \\
\hline
\end{tabular}

NUMBER OF REFERENCES

36

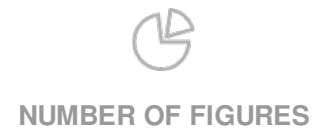

0
NUMBER OF TABLES

3

(C) The author(s) 2021. This publication is an open access article. 


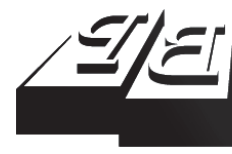

\section{BUSINESS PERSPECTIVES}

(2)

LLC "CPC "Business Perspectives" Hryhorii Skovoroda lane, 10, Sumy, 40022, Ukraine www.businessperspectives.org

Received on: $20^{\text {th }}$ of March, 2021 Accepted on: $30^{\text {th }}$ of July, 2021 Published on: $29^{\text {th }}$ of September, 2021

(C) Oluwaseyi Olalere, Md. Aminul Islam, Marniati, Nurulul Rahmi, 2021

Oluwaseyi Olalere, Postdoctoral Research Fellow, Graduate School of Business, University of Cape Town, South Africa. (Corresponding author)

Md. Aminul Islam, Professor, Faculty of Applied Science and Humanities, Universiti Malaysia Perlis, Malaysia.

Marniati, Lecturer, Faculty of Health Sciences, Ubudiyah Indonesia University, Indonesia.

Nurulul Rahmi, Lecturer, Faculty of Health Sciences, Ubudiyah Indonesia University, Indonesia
Oluwaseyi Olalere (South Africa), Md. Aminul Islam (Malaysia),

Marniati (Indonesia), Nurulul Rahmi (Indonesia)

THE EFFECT OF REVENUE

DIVERSIFICATION ON THE FIRM

VALUE AND STABILITY OF BANKS:

A COMPARATIVE STUDY

OF NIGERIAN AND MALAYSIAN

BANKS

\begin{abstract}
This study contributes to the current debate on the downsides and benefits of revenue diversification. Diversification may affect banks when they invest in riskier activities with lower returns, while they benefit from diversified activities that are less risky but have higher returns. The study offers extended implications in the empirical literature using a different measure of revenue diversification from an emerging market perspective. The study uses recent financial data from 26 Malaysian and Nigerian banks for the period 2009-2017, totaling 234 observations. The GMM estimation technique is employed to test the relationship. The results show that revenue diversification - noninterest income/gross revenue ratio (NII), fee and commission income/revenue ratio (NII1), and non-interest income/total assets ratio (NIITA) - significantly affect the firm value and stability of Nigerian banks. Liquidity, administrative expenses, net interest margin (NIM), non-performing loans (NPL), size, GDP growth rate and inflation also affect the firm value and stability of a bank. For Malaysian banks, diversification variables do not significantly affect firm value of a bank, while liquidity, administrative expenses, NIM and size significantly affect firm value. Diversification (NII and NIITA), liquidity, administrative expenses, NIM, NPL, size, GDP growth and inflation rate has a significant impact on the stability of Malaysian banks. The study concludes that revenue diversification affects both the firm value and stability of banks, and to achieve sound financial stability, banks that focus on interest-generating activities may diversify into non-interest-generating activities.
\end{abstract}

Keywords

GMM estimation, banks, emerging markets, revenue diversification, firm value

JEL Classification $\quad$ C58, G21, G32

\section{INTRODUCTION}

The steady shift from traditional to non-traditional activities is debatable, both theoretically and empirically, as it is assumed to reduce cyclical fluctuations in bank performance and revenue. Bank profitability declines when sources of interest income become uncertain following the financial distress. The decline in deposits and the increase in failure of balance sheets of banks to provide loans make traditional banking activity less profitable. For example, bank lending (Pennathur et al., 2012) will be less essential. Commercial banks must extend a new model of their financial intermediary stature to ensure financial system stability (Chiorazzo et al., 2008), by combining both traditional and non-traditional businesses. In developing markets, the state of the banking industry is critically important, since banks play a major role in funding corporations. Commercial banks have substituted their patterns of business through the combination of a wide variety of 
commercial services to enhance revenue (Elsas et al., 2010). This subject has been discussed extensively until now (Stiroh \& Rumble, 2006), given that the aggregate level of risk is imperative for the stability of the banking sector (Baele et al., 2007).

The economic literature, however, has strongly focused on advanced countries (primarily the US and European economies) in terms of their diversification impacts on bank value and risk. Emerging economies are still partly studied according to our finest understanding (see Berger et al., 2010; Hidayat et al., 2012; Lin et al., 2012; Nguyen et al., 2012a; Lee et al., 2014a, 2014b). This can be due to low levels of disclosure, as well as imperfection and immaturity of developing markets. Moreover, the results of past studies (in connection with the developed economy) could not be generalized to emerging economies because the operating and regulatory ambience where the banks operate differ, namely, the variance in the maturity of the market, variability in the level of bank freedom, existence, or lack of restrictions on activity and compliance.

There was no agreement on the influence of income diversification on profitability and risk, despite the richness of the diversification literature. While some surveys have shown the adverse impact of product diversification in developed countries (Lepetit et al., 2008; Stiroh \& Rumble, 2006; Stiroh, 2004; Acharya et al., 2002), most empirical surveys in emerging markets have demonstrated a strong association between income diversification and bank performance (Lin et al., 2012; Nguyen et al., 2012a; Lee et al., 2014a). This study provides a comprehensive and comparative empirical analysis between developing and emerging markets and bridges gaps in the empirical literature by integrating various measures of revenue diversification using a robust estimation to derive a conclusive finding.

The joint effect of traditional and non-traditional revenue diversification of banks is still poorly understood in emerging countries, leading to a lack of research in the economic literature. Hence, this study includes certain bank-specific factors and other variables, which in prior empirical research have often been overlooked and appear to significantly affect the firm value (FV) and stability of banks (Hamdi et al., 2017).

\section{LITERATURE REVIEW AND HYPOTHESES DEVELOPMENT}

The theory offers conflicting projections about the effect of higher diversification of operations on economic intermediaries' performance. Existing theories of economic intermediation indicate growing yields to scale related to diversification. As proposed by Stein (2002), Saunders and Walter (1994), and Rajan (1992), banks obtain client data in the process of creating credit that can promote the effective provision of other financial services, including securities underwriting. Similarly, underwriting of bonds, insurance and brokerage and mutual fund services and other operations can generate data and/or information that increases the creation of loans.

The study begins by assessing the current litera- ture to ascertain how this paper could contribute to the increasing revenue diversification and profitability literature. There are currently three primary strands of literature on empirical diversification. The first part emphasizes the advantages of diversification. The second part shows the gloomy side impacts of the diversification of revenues by the bank. Lastly, the third part explicates on the contribution of diversification to uncertain results.

The first part highlights the bright side of bank income diversification of banks in developing and emerging countries. Either European or US is the most representative research that focused on advanced countries. For instance, Chiorazzo et al. (2008) used the fixed-effect panel model to document a beneficial impact of revenue diversification for tiny Italian companies that began with low non-interest incomes. By extending their study's geographic coverage, Elsas et al. (2010) discovered that diversification would directly enhance 
bank efficiency through synergies supplied by the economical scope and its market value indirectly. These results coincided with Sawada (2013), who reported a significant risk reduction potential through diversification of income sources to fee operations, whilst the relationship between interest and non-interest earnings was either weak or negative.

In the case of emerging-country banks, some studies have shown that banks can benefit from the diversification of revenues. Pennathur et al. (2012) found that the shift to non-traditional business would be affected differently depending on the type of a bank. Using sys-GMM for 29 nations in the Asia-Pacific region, Lee et al. (2014a) concluded that fees and other non-interest revenues could result in enhanced stability and profits and reduced risks for the banking business.

While the previous literature has shown a positive effect of strategic shifts on bank performance, the opposite conclusion was supported by the second part of the literature on diversification. Stiroh (2004) first discovered that enhanced reliability on non-interest earnings did not generate benefit by using distinct empirical methodologies, particularly if the elements of working income (fees and interest-revenue service charges) were extremely correlated and the elevated volatility of trade income kept the adverse impacts of diversification. To allow greater insight, Stiroh and Rumble (2006) proved that greater dependence on non-interest income generated reduces risk-adjusted profitability as non-traditional enterprises' volatility is higher than any benefits of diversification.

The conclusions of Stiroh and Rumble (2006) has been confirmed by Mercieca et al. (2007), who document that their risk-adjusted performance in small European loan organizations has decreased, as they have concentrated on non-traditional activities. After checking the key variables determining the state of the macro-economic setting, distinct samples, bank types were powerful and robust. Lepetit et al. (2008) emphasized finally that higher dependence on fees and commission-generating activities increased the likelihood of default risks for European trade and cooperative banks.
The third part of the literature explicates how revenue diversification has different effects on firm performance. Acharya et al. (2002) began with studies of banks in developed countries to highlight improvements in the risk return of Italian medium-risk commercial banks. However, the performance of banks would be impaired by sectorial and industrial diversification. Baele et al. (2007) posit diversification would increase bank market value on a separate line of reasoning. Unlike other studies, Goddard et al. (2008) made considerable efforts to assess the economic performance of 5,784 US loan unions during 1993-2004 due to the revenue diversification. The findings of the study had a favorable direct exposure impact on the adjusted and unadjusted risk income, indicating that yields would decline as loan unions seek to diversify. Lee et al. (2014b), using bank data from 22 Asian nations and 967 individual banks for the period 1995-2009, explored the impact of non-interest revenue on the performance and risks of banks. The findings show that the non-interest activities of Asian banks reduce the risk but do not improve profitability using the dynamic panel (GMM).

Sun et al. (2017) recently explored the influence of non-interest income on bank performance from 2007 to 2013. The empirical results show a nonlinear link between non-interest income and the performance of a bank using a panel threshold model. Furthermore, the findings show that the nexus between the non-interest income ratio and bank performance is negative. It was noted that the non-interest income ratio should be improved to a certain degree to make banks more profitable. Some literary sources say that non-interest income obtained from bank diversification increase the risk of banking. For instance, for the period between 2000 and 2009, Delpachitra and Lester (2013) examined the effect of diversification of banks and revealed a decline in profitability. In another study, the impact of non-interest income on the bank returns and risk was examined by Williams and Prather (2010). The findings argue that fee-based income seems riskier than interest income but provides bank shareholders diversification advantages. This study focuses on emerging markets, where there is relatively little research, while most previous studies have focused on developed economies. This study filled the gap by examining the influence of revenue diversification on firm value and stability of banks in Nigeria and Malaysia. 


\subsection{Hypotheses development}

The empirical evidence generally showed that bank diversification and bank performance have a positive association. These results were also obtained for the US, Europe, and other bank samples. Sanya and Wolfe (2011) also provide evidence of a positive relationship between revenue diversification and return of banks from an emerging country perspective. Besides, the positive nexus between diversification and banking return for Asian banks has also been confirmed (Lee et al., 2014b). While there is generally homogenous evidence on the relationship between revenue diversification and profitability, it is difficult to affirm the same for the association between revenue diversification and stability.

De Jonghe (2010) and Calmès and Liu (2009), for example, found more evidence of diversification connected to bank risk in the USA, Europe, and Canada. However, findings from banks from emerging and Asian market showed that income diversification decreases risk (Lin et al., 2012; Lee et al., 2014a). Sanya and Wolfe (2011) identify a few distinctive and common features among emerging economies, including underdeveloped institutions, and lack of expertise in liberalized financial markets, with significant effects on their financial systems. In this respect, Nigerian and Malaysian banks are more likely to be similar to banks from other developing countries. The study hypothesizes a significant relationship between revenue diversification and stability of a bank as follows:

\section{$H_{1}: \quad$ Revenue diversification significantly influ- ences the firm value of a bank.}

$\mathrm{H}_{2}: \quad$ Revenue diversification significantly influences the stability of a bank.

\section{METHODOLOGY}

This section details the data sources, highlights the model specifications, and various measurements of diversification, firm value, and stability.

\subsection{Data sources and definitions}

The study uses data obtained from financial statements that are used in various cross-country studies. Data include a sample of a balanced panel of data for 26 banks for the period 2009-2017 with a focus on Nigerian and Malaysian banks. A total of sixteen (16) Nigerian banks and ten (10) Malaysian banks were selected. However, the commercial banks that do not have complete financial data during the period selected were excluded from the sample. The macro-economic data are obtained from the World Bank Indicator.

The study employed the firm value as a measure of long-term performance, calculated as enterprise value as a percentage of earnings before interest, taxes, depreciation and amortization (Lifland, 2011). The measurement is preferred because it offers predicted returns to investors and acquirers and costs that are useful in valuing a bank, which is the overall market value of the bank. Bank stability is a proxy by Z-score and its measure as the addition of ROAA and capital adequacy divided by ROAA (Nguyen et al., 2012b). The revenue diversification measure includes the non-interest income/gross revenues ratio (NII), fee and commission income/gross revenues ratio (NII1) and non-interest income/total assets ratio (NIITA) (Meslier et al., 2014; Nguyen et al., 2012a; Lepetit et al., 2008).

The control variables used include the ratio of non-performing loans to total loans, NIM proxy by the net interest income to interest interest-earning assets, administrative expenses are measured by non-interest expenses to average assets, liquidity proxy by liquid assets to total assets, bank size, GDP growth rate and inflation rate (Dietrich \& Wanzenri, 2011; Zhang \& Daly, 2013; Nguyen, 2012b; Ebenezer et al., 2018).

\subsection{Model specification}

The study uses dynamic panel data (GMM) to tackle the problems of intrinsic endogeneity, heteroscedasticity, and autocorrelation. By using a two-step GMM estimator, the typical heteroscedasticity issues are solved in the models. The lags of a dependent variable were incorporated in the model under the dynamic model estimation. Before the dynamic panel estimation is analyzed, the Sargan test and Arellano-Bond test were conducted to check for second order autocorrelation. The study accepts the null hypothesis when the Sargan test's p-values are greater than 5 per- 
cent; this means that the models used and the over-identifying constraints are valid.

$$
\begin{aligned}
& F V_{i t}=\alpha_{0}+\delta F_{i t-1}+ \\
& +\sum_{a=1}^{a} \beta_{a} \text { DiversificationVar }_{t}^{a}+ \\
& +\sum_{b=1}^{b} \beta_{b} \text { Bank Level Var }_{t}^{b}+ \\
& +\sum_{c=1}^{c} \beta_{c} \text { Macroeconomic Var }_{t}^{c}+ \\
& +v_{i t}+\mu_{i t}, \\
& Z_{s c o r e} e_{i t}=\alpha_{0}+\text { SZscore }_{i t-1}+ \\
& +\sum_{a=1}^{a} \beta_{a} \text { DiversificationVar }_{t}^{a}+ \\
& +\sum_{b=1}^{b} \beta_{b} \text { Bank LevelVar }_{t}^{b}+ \\
& +\sum_{c=1}^{c} \beta_{c} \text { Macroeconomic Var }_{t}^{c}+ \\
& +v_{i t}+\mu_{i t} .
\end{aligned}
$$

In the main model, the lag of the firm value measure is treated as endogenous in equation (1), the lag of the bank stability measure is treated as endogenous in equation (2), and all other variables are exogenous. The models where the variables are expressed in differences are shown above.

\section{RESULTS AND DISCUSSION}

\subsection{Descriptive statistics}

Table 1 provides descriptive statistics of revenue diversification, firm value, bank-level and macroeconomic factors used for individual and aggregate data.

Table 1 shows that the mean of firm value is $10 \%$ for Nigerian banks, while the mean for Malaysian banks is $0.1108(11 \%)$. The table depicts that the stability of Nigerian banks is $15 \%$, while that of Malaysian banks is $13 \%$. This implies that the Nigerian banking sector is more stable than the Malaysian banking sector. The table further reports that Malaysian banks are more diversified in terms of the non-interest income to gross revenue ratio with a mean of $26 \%$, while the mean of Nigerian banks stood at $25 \%$. The fee and commission to the gross revenue ratio (NII1) of Nigerian banks has a mean of $23 \%$, while Malaysian banks has a mean of $10 \%$. The non-interest income to total asset ratio

\begin{tabular}{|c|c|c|c|c|c|c|c|c|c|}
\hline Variables & No. & All banks mean & SD & No. & Nigerian mean & Banks SD & No. & Malaysian mean & Banks SD \\
\hline FV & 234 & 0.10838 & 0.04828 & 144 & 0.10680 & 0.05283 & 90 & 0.11089 & 0.04010 \\
\hline Zscore & 234 & 0.14727 & 0.13030 & 144 & 0.15282 & 0.08238 & 90 & 0.13839 & 0.18281 \\
\hline NII & 234 & 0.25893 & 0.09966 & 144 & 0.25789 & 0.11263 & 90 & 0.26060 & 0.07492 \\
\hline NIII & 234 & 0.18240 & 0.12167 & 144 & 0.23119 & 0.13227 & 90 & 0.10434 & 0.02515 \\
\hline NIITA & 234 & 0.02526 & 0.01620 & 144 & 0.02941 & 0.01388 & 90 & 0.01862 & 0.01748 \\
\hline NIEAA & 234 & 0.05043 & 0.06485 & 144 & 0.06725 & 0.07596 & 90 & 0.02351 & 0.02341 \\
\hline$N P L$ & 234 & 0.05176 & 0.11585 & 144 & 0.08238 & 0.13931 & 90 & 0.00277 & 0.00304 \\
\hline LATA & 234 & 0.13247 & 0.10991 & 144 & 0.15916 & 0.09796 & 90 & 0.08976 & 0.11492 \\
\hline NIM & 234 & 0.12715 & 0.07845 & 144 & 0.07557 & 0.03203 & 90 & 0.20966 & 0.05725 \\
\hline SIZE & 234 & 17.61066 & 02.66615 & 144 & 17.01952 & 03.15195 & 90 & 18.55649 & 01.08482 \\
\hline GDP & 234 & 0.03168 & 0.02317 & 144 & 0.02199 & 0.01665 & 90 & 0.04717 & 0.02379 \\
\hline INFL & 234 & 0.08122 & 0.05204 & 144 & 0.11788 & 0.02898 & 90 & 0.02255 & 0.00925 \\
\hline
\end{tabular}
(NIITA) of Nigerian banks averagely stood at $2 \%$, and that of Malaysian banks at $1.8 \%$. The table also reports that the non-interest expenses to average assets ratio (NIEAA) of Nigerian banks has a mean of $6 \%$, while Malaysian banks stood at $2 \%$.

The NPL ratio indicates that Nigerian banks have the highest rate of non-performing loans at $8 \%$, while Malaysian banks have an average of $0.2 \%$.

Table 1. Summary of descriptive statistics

Note: FV - Firm value; NII, NIII, and NIITA are diversification variables. 
Furthermore, the liquid asset ratio of Nigerian banks has a mean of $15 \%$, while Malaysian banks are at $8 \%$. The higher net interest margin (NIM) came from Malaysian banks with a mean of $20 \%$, while Nigerian banks are averagely at $7 \%$. The size has a mean value of 17 million for Nigerian banks, while the mean value for Malaysian banks is around 19 million. The Nigerian economy grew at an average of $2 \%$, while the mean of GDP growth is $4 \%$ for Malaysia. Lastly, inflation rate has a mean of $12 \%$ for Nigeria and $2 \%$ for Malaysia.

\subsection{Discussion}

The coefficient estimates of the analysis are presented in Table 2, with firm value as a dependent variable for both Nigerian and Malaysian banks. The diagnostic tests of the GMM estimator validate that the models in the study are specified correctly. Since the lag of firm value is significant and positive, this implies that the $\mathrm{FV}$ is persistence.

The results in Table 2 for Model 1 represent the aggregate banks in which NII, NII1 and NIITA are proxy diversification. Model 1 for all banks indi- cates that revenue diversification has a significant and negative association with FV. Model 2 of the study revealed that NII of Nigerian banks has a significant and negative effect on FV of banks. This indicates that a decrease in NII will lead to an increase in $F V$. The findings are inconsistent with Sanya and Wolfe (2011). Control variables, administrative expenses, show an insignificant relationship with firm value. Also, non-performing loans and liquid asset ratio both have a significant and negative effect on $F V$. The net interest margin, size and inflation rate show an insignificant association with $F V$. On the contrary, the GDP growth reveals a significant and positive effect on $F V$.

The empirical Model with fee and commission income (NIII) is found to have a significant and negative nexus with $F V$. This suggests that the fee and commission income is inversely linked to Nigerian commercial banks. Stiroh (2006) argues that the cross-selling of various products to similar consumers that do not necessarily generate diversification benefits justified the interactions of fee and commission with interest income. Predominantly, a bank offers both credit and non-credit facilities

Table 2. Firm value sys-GMM model results

\begin{tabular}{|c|c|c|c|c|c|c|c|c|c|}
\hline \multirow[t]{2}{*}{ Variables } & \multicolumn{3}{|c|}{$\begin{array}{l}\text { All banks } \\
\text { Model } 1\end{array}$} & \multicolumn{3}{|c|}{$\begin{array}{c}\text { Nigeria } \\
\text { Model } 2\end{array}$} & \multicolumn{3}{|c|}{$\begin{array}{l}\text { Malaysia } \\
\text { Model } 3\end{array}$} \\
\hline & Coef. & Coef. & Coef. & Coef. & Coef. & Coef. & Coef. & Coef. & Coef. \\
\hline L.FV & $.483^{* * *}$ & $300 * * *$ & $.154^{* * *}$ & $.494 * * *$ & $.374 * * *$ & $.281 * * *$ & -.161 & -.0935 & -.283 \\
\hline NII & $-.016^{* *}$ & - & - & $-.040 * * *$ & - & - & .335 & - & - \\
\hline NIII & - & $-.005^{*}$ & - & - & $-.039 * *$ & - & - & -.3077 & - \\
\hline NIITA & - & - & $-.009 * * *$ & - & - & $.0088^{* *}$ & - & - & 7.394 \\
\hline NIEAA & $-.022 * * *$ & -.003 & $-.008^{* * *}$ & -.007 & -.0098 & -0058 & -3.378 & $-.1562 *$ & -9.393 \\
\hline$N P L$ & $-.013 * *$ & $-.004^{* * *}$ & $-.004^{* * *}$ & $-.049 * * *$ & $-.052 * * *$ & $-.039 * * *$ & .574 & -15.828 & 2.137 \\
\hline LATA & $-.094 * * *$ & $-.091^{* * *}$ & $-.112 * * *$ & $-.017 * * *$ & $-.017 * * *$ & $-.0192 * * *$ & $-.165 * * *$ & $-.0315 * * *$ & $-.174 * * *$ \\
\hline NIM & $-1.040 * * *$ & $-.202^{* * *}$ & $-.218^{* * *}$ & -.011 & $-.013^{*}$ & $-.218^{* *}$ & $-.237^{*}$ & $-.136^{* *}$ & $-.354^{* *}$ \\
\hline SIZE & $-.020 * * *$ & $-.055^{* * *}$ & $-.149 * * *$ & .006 & -.074 & -.0191 & $-5.839 *$ & -1.448 & $-5.804 *$ \\
\hline GDP & $.006 * * *$ & $.001^{* *}$ & -.008 & $.0009 * * *$ & .0005 & $.0009 * * *$ & .077 & .6785 & -.0466 \\
\hline INFL & $-.276 * *$ & -.001 & $.001^{*}$ & -.041 & $-.0097 * *$ & $-.0758^{* *}$ & -.053 & -.232 & .0458 \\
\hline cons & $-1.139 * * *$ & $-.248^{* * *}$ & $-.204^{*}$ & $-.144 * *$ & -.476 & $-.2568^{* * *}$ & $1.266^{*}$ & -3.209 & $1.3945^{*}$ \\
\hline$A R 1$ & $\begin{array}{c}-1.997 \\
(0.0458)\end{array}$ & $\begin{array}{c}-1.913 \\
(0.0557)\end{array}$ & $\begin{array}{c}-2.399 \\
(0.0164)\end{array}$ & $\begin{array}{c}-2.229 \\
(0.0258)\end{array}$ & $\begin{array}{l}-2.126 \\
(0.0335)\end{array}$ & $\begin{array}{c}-2.490 \\
(0.0128)\end{array}$ & $\begin{array}{c}-.8798 \\
(0.3790)\end{array}$ & $\begin{array}{c}.1154 \\
(0.9081)\end{array}$ & - \\
\hline$A R 2$ & $\begin{array}{c}.7027 \\
(0.4822)\end{array}$ & $\begin{array}{c}.6634 \\
(0.5070)\end{array}$ & $\begin{array}{c}.9006 \\
(.3678)\end{array}$ & $\begin{array}{c}.0177 \\
(0.9859)\end{array}$ & $\begin{array}{c}.0567 \\
(0.9547)\end{array}$ & $\begin{array}{c}.1832 \\
(0.8546)\end{array}$ & $\begin{array}{c}.1850 \\
(0.8532)\end{array}$ & $\begin{array}{c}-.7150 \\
(0.4746)\end{array}$ & $\begin{array}{c}.2132 \\
(0.8312)\end{array}$ \\
\hline Hansen Test & $\begin{array}{c}13.33 \\
(0.9994)\end{array}$ & $\begin{array}{c}13.80 \\
(0.9992)\end{array}$ & $\begin{array}{c}13.002 \\
(0.9996)\end{array}$ & $\begin{array}{c}8.464 \\
(1.0000)\end{array}$ & $\begin{array}{c}8.057 \\
(1.0000)\end{array}$ & $\begin{array}{c}5.0643 \\
(1.0000)\end{array}$ & $\begin{array}{c}43.965 \\
(0.1177)\end{array}$ & $\begin{array}{c}42.425 \\
(0.1522)\end{array}$ & $\begin{array}{c}43.177 \\
(0.1345)\end{array}$ \\
\hline F Test & $\begin{array}{c}292.62 \\
(0.0000)\end{array}$ & $\begin{array}{c}446.33 \\
(0.0000)\end{array}$ & $\begin{array}{c}831.21 \\
(0.0000)\end{array}$ & $\begin{array}{c}1136.33 \\
(0.0000)\end{array}$ & $\begin{array}{c}542.05 \\
(0.0000)\end{array}$ & $\begin{array}{l}1326.97 \\
(0.0000)\end{array}$ & $\begin{array}{c}241.01 \\
(0.0000)\end{array}$ & $\begin{array}{c}236.39 \\
(0.0000)\end{array}$ & $\begin{array}{c}185.75 \\
(0.0000)\end{array}$ \\
\hline $\begin{array}{l}\text { No of } \\
\text { Instruments }\end{array}$ & 44 & 44 & 44 & 44 & 44 & 44 & 44 & 44 & 44 \\
\hline Observations & 234 & 234 & 234 & 144 & 144 & 144 & 90 & 90 & 90 \\
\hline
\end{tabular}

Note: $* * *, * *$, and $*$ denote significance at $1 \%, 5 \%$, and $10 \%$, respectively. 
to investment customers that simultaneously generate fee and commission income.

Another different proxy of diversification (NIITA), such as in the study by Nisar et al. (2018), was used. The Model with NIITA indicates a significant and positive nexus with FV. This finding provides support to the review of studies that diversification can assist banks in Nigeria to enhance $F V$. The non-performing loan has a significant and negative effect on FV. This means that non-performing loans contribute to the low $F V$ for banks in Nigerian markets. This could be attributable to the upsurge in the rate of default triggered from rickety in the economic conditions of an emerging economy. Similarly, liquidity, net interest margin and inflation rate have a significant negative impact on $F V$. This suggests that the reduction in this control variables will lead to improved value of a firm. However, the GDP growth rate shows a positive association with $F V$.

Model 3 that represents Malaysian banks shows that all the diversification measures (NII, NII1 and NIITA) are insignificant with FV. Liquidity, net interest margin and size show a significant and negative effect on $F V$ for the Model with NII. Moreover, there is a negative and significant relationship between administrative expenses (NIEAA), liquidity, net interest margin and $F V$ for the Model with fees and commission to gross revenue (NII1) as a measure of diversification. The negative and significant relationship implies the need for a decline in the administrative expenses of Nigerian banks. Finally, liquidity, net interest margin and size reveal a significant negative effect of the value of a firm for the Model with NIITA as a measure of diversification. The insignificant effect of diversification measures implies that Malaysian banks are not diversified but specialized in their operational and revenue activities. This study found that the first hypothesis $\left(H_{1}\right)$ indicates that revenue diversification has a significant impact on the firm value of banks.

The sys-GMM Model with bank stability shows that the lag (L.Zscore) is significantly positive for all the Models (see Table 3). Model 5 revealed that NII has a significant and positive impact on bank stability. This means that NII contributes

Table 3. Bank stability (Z-score) sys-GMM model results

\begin{tabular}{|c|c|c|c|c|c|c|c|c|c|}
\hline \multirow[t]{2}{*}{ Variables } & \multicolumn{3}{|c|}{$\begin{array}{l}\text { All banks } \\
\text { Model } 4\end{array}$} & \multicolumn{3}{|c|}{$\begin{array}{c}\text { Nigeria } \\
\text { Model } 5\end{array}$} & \multicolumn{3}{|c|}{$\begin{array}{l}\text { Malaysia } \\
\text { Model } 6\end{array}$} \\
\hline & Coef. & Coef. & Coef. & Coef. & Coef. & Coef. & Coef. & Coef. & Coef. \\
\hline L.Zscore & $.684^{* * *}$ & $.6289 * * *$ & $.6350 * * *$ & $.2567 * * *$ & $.5142 * * *$ & $.3306 * * *$ & $.638 * * *$ & $2.540 * * *$ & $.9526 * * *$ \\
\hline NII & $-.054 * * *$ & - & - & $.172 *$ & - & - & $-.1613^{* * *}$ & - & - \\
\hline NIII & - & $-.314^{* * *}$ & - & - & $-4.931^{*}$ & - & - & -.286 & - \\
\hline NIITA & - & & $1.774 * * *$ & - & - & $.0158 * * *$ & - & - & $6.399 *$ \\
\hline NIEAA & $.081^{* * *}$ & $.039 * * *$ & $.0790 * * *$ & $.043^{* * *}$ & $-1.464^{*}$ & $.0420 * * *$ & $6.030 * * *$ & -14.750 & -.0236 \\
\hline$N P L$ & $-.053^{* * *}$ & $-.036 * * *$ & $-.087 * * *$ & $-.009 * *$ & $-.306^{* * *}$ & $-.0075^{*}$ & 4.236 & $-36.051^{* *}$ & -.0074 \\
\hline LATA & $.034 * * *$ & $.0307 * * *$ & $.053 * * *$ & $-.011 * * *$ & -.274 & $-.0060^{*}$ & $.1208^{* *}$ & $-.6036^{*}$ & -.3165 \\
\hline NIM & $.1992 * * *$ & $.2298^{* * *}$ & $.172 * * *$ & .004 & -19.698 & .0041 & $.0881^{* * *}$ & $-.2737^{* *}$ & .1817 \\
\hline SIZE & $.085 * * *$ & $.1656^{* * *}$ & $.748^{* * *}$ & $-2.528^{*}$ & .9653 & -.719 & $15.280 * * *$ & -4.0487 & $5.903^{* *}$ \\
\hline GDP & $-.607 * * *$ & $-.289 * * *$ & $-.784^{* * *}$ & -.0013 & $12.396^{* *}$ & $-.0022^{*}$ & $.8463^{*}$ & $.1660^{* * *}$ & $6.357^{*}$ \\
\hline INFL & $.0200 * *$ & $-.012 * * *$ & $.025^{*}$ & -.0016 & 3.140 & .0285 & $-1.180 * *$ & $-2.798 * *$ & $-7.696^{*}$ \\
\hline cons & $-.193 * * *$ & $470 * * *$ & $-.130 * * *$ & $.4350 *$ & 1.1006 & .2301 & $-3.051^{* * *}$ & -4.949 & $9.810 *$ \\
\hline$A R 1$ & $\begin{array}{l}-1.5734 \\
(0.1156)\end{array}$ & $\begin{array}{l}-1.6191 \\
(0.1054)\end{array}$ & $\begin{array}{c}-1.451 \\
(0.1467)\end{array}$ & $\begin{array}{l}-1.175 \\
(0.2400)\end{array}$ & $\begin{array}{l}-1.3363 \\
(0.1815)\end{array}$ & $\begin{array}{l}-1.2356 \\
(0.2166)\end{array}$ & $\begin{array}{l}-1.7324 \\
(0.1206)\end{array}$ & $\begin{array}{c}-.6380 \\
(0.5234)\end{array}$ & $\begin{array}{c}-.2949 \\
(0.7680)\end{array}$ \\
\hline$A R 2$ & $\begin{array}{c}-.3551 \\
(0.7225)\end{array}$ & $\begin{array}{c}-.2529 \\
(0.8003)\end{array}$ & $\begin{array}{l}-.1603 \\
(0.8726)\end{array}$ & $\begin{array}{c}.6879 \\
(0.4915)\end{array}$ & $\begin{array}{c}1.0381 \\
(0.2992)\end{array}$ & $\begin{array}{c}.8074 \\
(0.4194)\end{array}$ & $\begin{array}{l}-.4240 \\
(0.6715)\end{array}$ & $\begin{array}{c}.7905 \\
(0.3628)\end{array}$ & $\begin{array}{c}-.6211 \\
(0.5345)\end{array}$ \\
\hline Hansen Test & $\begin{array}{c}22.996 \\
(0.9237)\end{array}$ & $\begin{array}{c}18.227 \\
(0.9876)\end{array}$ & $\begin{array}{c}23.490 \\
(0.9119)\end{array}$ & $\begin{array}{c}6.5925 \\
(1.0000)\end{array}$ & $\begin{array}{c}7.9517 \\
(1.0000)\end{array}$ & $\begin{array}{c}6.9093 \\
(1.0000)\end{array}$ & $\begin{array}{c}41.127 \\
(0.1867)\end{array}$ & $\begin{array}{l}1.13 e-14 \\
(1.0000)\end{array}$ & $\begin{array}{l}6.38 \mathrm{e}-17 \\
(1.0000)\end{array}$ \\
\hline F Test & $\begin{array}{c}40893.47 \\
(0.0000)\end{array}$ & $\begin{array}{c}26158.76 \\
(0.0000)\end{array}$ & $\begin{array}{l}19547.77 \\
(0.0000)\end{array}$ & $\begin{array}{c}129.08 \\
(0.0000)\end{array}$ & $\begin{array}{c}59.88 \\
(0.0000)\end{array}$ & $\begin{array}{c}314.54 \\
(0.0000)\end{array}$ & $\begin{array}{l}1535.86 \\
(0.0000)\end{array}$ & $\begin{array}{c}997.54 \\
(0.0000)\end{array}$ & $\begin{array}{l}4568.29 \\
(0.0000)\end{array}$ \\
\hline $\begin{array}{l}\text { Number of } \\
\text { instruments }\end{array}$ & 44 & 44 & 44 & 44 & 44 & 44 & 44 & 44 & 44 \\
\hline Observations & 234 & 234 & 234 & 144 & 144 & 144 & 90 & 90 & 90 \\
\hline
\end{tabular}

Note: $* * *, * *$, and $*$ indicate significance at $1 \%, 5 \%$, and $10 \%$, respectively. 
to the improvement of bank stability in Nigeria. The results also confirm that the administrative expenses and stability (Z-score) nexus is significantly positive, while non-performing loans, liquidity and size have a significant and negative impact on bank stability (Z-score). Other variables are insignificant with bank stability. The fee and commission to gross revenue ratio (NII1) shows a significant and negative influence on financial stability. Also, administrative expenses and non-performing loans have a significant and negative relationship with stability. Conversely, the GDP growth rate has a significant and positive impact on bank stability. This suggests that a favorable economic growth positively influences the stability of Nigerian banks.

The result with the non-interest income to average asset (NIITA) confirms a significant and positive impact on bank stability, signifying that NIITA increases the stability of Nigerian banks. This is in line with Pennathur et al. (2012) and Ahamed (2017). Administrative expenses (NIEAA) have a significant and negative impact on bank stability, while non-performing loans, liquidity and GDP growth indicate a significant and negative association with bank stability. Model 6 with non-interest income (NII) asserts a significant and negative impact on bank stability of Malaysia. Administrative expenses, liquidity, net interest margin, size and GDP all have a significant and positive impact on the stability of banks. This implies that the control variables contribute to the improvement of bank stability in Malaysia. The positive liquidity relations with bank stability imply that satisfactory levels of liquidity guarantee superior stability by guarding against the insolvency risk. The result with fee and commission to gross revenue (NII1) has an insignificant impact on bank stability.

Nonetheless, non-performing loans have a significant and positive impact on stability. This means that non-performing assets threaten the long-term stability of Malaysian banks. The regulators of Malaysian banks should make effort in controlling and improving the quality of their credit portfolios. This result is consistent with Pennathur et al. (2012) and Lee et al. (2014b). Similarly, liquidity, NIM and inflation rate all have a significant and negative impact on bank stability, while GDP growth is significant and positively related with the stability of banks. In addition, the result with NIITA has a significant and positive impact on bank stability. This is consistent with Pennathur et al. (2012) and Ahamed (2017), implying that an improvement in NIITA will increase bank stability, ceteris paribus. Likewise, bank size and GDP growth both have a positive and significant impact on bank stability (Z-score), while there is a significant and negative effect of inflation rate on bank stability among Malaysian banks. Hence, this study found that the second hypothesis $\left(H_{2}\right)$ indicates that revenue diversification has a significant impact on the stability of banks.

\section{CONCLUSION}

This study examines the influence of revenue diversification on the firm value and stability of banks. In the study, diversification is divided into non-interest income and fees and commission income, respectively. The findings of the study revealed that diversification - non-interest income to gross revenue (NII), non-interest income to total assets (NIITA), and fee and commission to gross revenue (NII1) - has a significant negative effect on FV, while NII and NII1 have a significant negative effect and NIITA has a significant and positive impact on the stability of banks. The findings are robust as the study uses various revenue diversification measures. This study offers a unique contribution to the investigation of commercial banks with non-traditional intermediation activities that generate non-interest income from an emerging market perspective.

The findings suggest some vital regulatory implications for banks in Malaysia and Nigeria, as well as other emerging countries. The study draws important conclusions and recommends that banks that engage in interest-generating activities diversify into non-interest generating activities 
to achieve the benefits that come with rising trends in the sector to achieve a competitive advantage over their close rivals. Hence, commercial banks that have already engaged in both interest and non-interest income activities can boost and/or augment their non-interest income portfolio with a careful diversification into other non-interest income areas as an alternative to fee and commission income.

From an investor perspective, it is imperative to choose banks with improved strategies in revenue diversification, since traditional interest-based and non-interest income generating products have different risk implications. For regulators and policy makers, the results emphasize the importance of allowing banks in developing and emerging markets to diversify their product offerings by reducing activity restrictions. However, care should be taken to ensure that banks (especially dominant banks) engage in non-traditional activities, since the increased overall bank risk may be related to their sources of income.

\section{AUTHOR CONTRIBUTIONS}

Conceptualization: Oluwaseyi Olalere, Md. Aminul Islam, Marniati.

Data curation: Oluwaseyi Olalere, Md. Aminul Islam, Marniati, Nurulul Rahmi.

Formal analysis: Oluwaseyi Olalere, Nurulul Rahmi.

Funding acquisition: Md. Aminul Islam, Marniati.

Investigation: Oluwaseyi Olalere, Md. Aminul Islam.

Methodology: Oluwaseyi Olalere, Md. Aminul Islam, Marniati, Nurulul Rahmi.

Project administration: Md. Aminul Islam, Marniati.

Software: Oluwaseyi Olalere, Marniati.

Supervision: Md. Aminul Islam, Marniati, Nurulul Rahmi.

Validation: Oluwaseyi Olalere, Md. Aminul Islam, Marniati, Nurulul Rahmi.

Visualization: Oluwaseyi Olalere, Md. Aminul Islam, Marniati.

Writing - original draft: Oluwaseyi Olalere, Md. Aminul Islam, Nurulul Rahmi.

Writing - reviewing \& editing: Oluwaseyi Olalere, Md. Aminul Islam, Marniati.

\section{REFERENCES}

1. Acharya, V. V., Saunders, A., \& Hasan, I. (2002). The effects of focus and diversification on bank risk and return: evidence from individual bank loan portfolios (NYU Working Paper No. FIN01-060). Retrieved from https:// papers.ssrn.com/sol3/papers. cfm?abstract_id $=1294605$

2. Ahamed, M. (2017). Asset quality, non-interest income, and bank profitability: Evidence from Indian banks. Economic Modelling, 63, 1-14. https:// doi.org/10.1016/j.econmod.2017.01.016

3. Baele, L., De Jonghe, O., \& Vennet, R. V. (2007). Does the stock market value bank diversification? Journal of Banking \& Finance, 31(7), 1999
2023. https://doi.org/10.1016/j. jbankfin.2006.08.003

4. Berger, A. N., Hasan, I., \& Zhou, M. (2010). The effects of focus versus diversification on bank performance: Evidence from Chinese banks. Journal of Banking \& Finance, 34(7), 1417 1435. https://doi.org/10.1016/j. jbankfin.2010.01.010

5. Calmes, C., \& Liu, Y. (2009). Financial structure change and banking income: A Canada - US comparison. Journal of International Financial Markets, Institutions and Money, 19(1), 128-139. https://doi. org/10.1016/j.intfin.2007.09.003

6. Chiorazzo, V., Milani, C., \& Salvini, F. (2008). Income diversification and bank performance: Evidence from Italian banks. Journal of Financial Services Research 33(3), 181-203. https://doi. org/10.1007/s10693-008-0029-4

7. De Jonghe, O. (2010). Back to the basics in banking? A microanalysis of banking system stability. Journal of financial intermediation, 19(3), 387-417. Retrieved from https://ideas. repec.org/a/eee/jfinin/v19y2010i3p387-417.html

8. Delpachitra, S., \& Lester, L. (2013). Non-interest income: are Australian banks moving away from their traditional businesses? Economic Papers: A journal of applied economics and policy, 32(2), 190-199. https://doi. org/10.1111/1759-3441.12032 
9. Dietrich, A., \& Wanzenried, G. (2011). Determinants of bank profitability before and during the crisis: Evidence from Switzerland. Journal of International Financial Markets, Institutions and Money, 21(3), 307-327. https://doi. org/10.1016/j.intfin.2010.11.002

10. Ebenezer, O. O., Islam, M. A., Yusoff, W. S., \& Sobhani, F. A. (2018). Exploring Liquidity Risk and Interest-Rate Risk: Implications for Profitability and Firm Value in Nigerian Banks. Journal of Reviews on Global Economics, 8, 315-326. https://doi.org/10.6000/19297092.2019.08.27

11. Elsas, R., Hackethal, A., \& Holzhäuser, M. (2010).

The anatomy of bank diversification. Journal of Banking \& Finance, 34(6), 12741287. https://doi.org/10.1016/j. jbankfin.2009.11.024

12. Goddard, J., McKillop, D., \& Wilson, J. O. (2008). The diversification and financial performance of US credit unions. Journal of Banking \& Finance, 32(9), 1836-1849. https://doi.org/10.1016/j.jbankfin.2007.12.015

13. Hamdi, H., Hakimi, A., \& Zaghdoudi, K. (2017). Diversification, bank performance and risk: have Tunisian banks adopted the new business model? Financial Innovation, 3(1), 1-25. https:// doi.org/10.1186/s40854-0170069-6

14. Hidayat, W. Y., Kakinaka, M., \& Miyamoto, H. (2012). Bank risk and non-interest income activities in the Indonesian banking industry. Journal of Asian Economics, 23(4), 335343. https://doi.org/10.1016/j. asieco.2012.03.008

15. Lee, C. C., Hsieh, M. F., \& Yang, S. J. (2014a). The relationship between revenue diversification and bank performance: Do financial structures and financial reforms matter? Japan and the World Economy, 29, 18-35. https://doi.org/10.1016/j.japwor.2013.11.002
16. Lee, C. C., Yang, S. J., \& Chang, C. H. (2014b). Non-interest income, profitability, and risk in banking industry: A cross-country analysis. The North American Journal of Economics and Finance, 27, 4867. https://doi.org/10.1016/j. najef.2013.11.002

17. Lepetit, L., Nys, E., Rous, P., \& Tarazi, A. (2008). Bank income structure and risk: An empirical analysis of European banks. Journal of Banking \& Finance, 32(8), 1452-1467. https://doi.org/10.1016/j.jbankfin.2007.12.002

18. Lifland, S. (2011). The impact of working capital efficiencies on the enterprise value option: Empirical analysis from the energy sector. Advances in Business Research, 2(1), 57-70. Retrieved from https://journals. sfu.ca/abr/index.php/abr/article/ view/51/33

19. Lin, J. R., Chung, H., Hsieh, M. H., \& Wu, S. (2012). The determinants of interest margins and their effect on bank diversification: Evidence from Asian banks. Journal of Financial Stability, 8(2), 96-106. https://doi. org/10.1016/j.jfs.2011.08.001

20. Mercieca, S., Schaeck, K., \& Wolfe, S. (2007). Small European banks: Benefits from diversification? Journal of Banking \& Finance, 31(7), 19751998. https://doi.org/10.1016/j. jbankfin.2007.01.004

21. Meslier, C., Tacneng, R., \& Tarazi, A. (2014). Is bank income diversification beneficial? Evidence from an emerging economy. Journal of International Financial Markets, Institutions and Money, 31, 97126. https://doi.org/10.1016/j. intfin.2014.03.007

22. Nguyen, M., Skully, M., \& Perera, S. (2012a). Bank market power and revenue diversification: Evidence from selected ASEAN countries. Journal of Asian Economics, 23(6), 688-700. https://doi.org/10.1016/j. asieco.2012.08.004
23. Nguyen, M., Skully, M., \& Perera, S. (2012b). Market power, revenue diversification and bank stability: Evidence from selected South Asian countries. Journal of International Financial Markets, Institutions and Money, 22(4), 897-912. https://doi. org/10.1016/j.intfin.2012.05.008

24. Nisar, S., Peng, K., Wang, S., \& Ashraf, B. (2018). The impact of revenue diversification on bank profitability and stability: Empirical evidence from South Asian countries. International Journal of Financial Studies, 6(2), 40. https://doi.org/10.3390/ ijfs6020040

25. Pennathur, A. K., Subrahmanyam, V., \& Vishwasrao, S. (2012). Income diversification and risk: Does ownership matter? An empirical examination of Indian banks. Journal of Banking \& Finance, 36(8), 2203-2215. https://doi.org/10.1016/j.jbankfin.2012.03.021

26. Rajan, R. (1992). Insiders and outsiders: the choice between informed and arm'slength debt. Journal of Finance, 47(4), 1367-1400. https://doi. org/10.1111/j.1540-6261.1992. tb04662.x

27. Sanya, S., \& Wolfe, S. (2011). Can banks in emerging economies benefit from revenue diversification? Journal of Financial Services Research, 40(12), 79-101. https://doi. org/10.1007/s10693-010-0098-Z

28. Saunders, A., \& Walter, I. (1994). Universal banking in the United States: What could we gain? What could we lose? New York: Oxford University Press.

29. Sawada, M. (2013). How does the stock market value bank diversification? Empirical evidence from Japanese banks. Pacific-Basin Finance Journal, 25(5), 40-61. https://doi. org/10.1016/j.pacfin.2013.08.001

30. Stein, J. (2002). Information production and capital allocation: decentralized versus hierarchical firms. Journal of Finance, 57(5), 1891-1921. 
Retrieved from https://scholar. harvard.edu/files/stein/files/ hierarchies-jf-final.pdf

31. Stiroh, K. J. (2004).

Diversification in banking: Is noninterest income the answer? Journal of Money, Credit, and Banking, 36(5), 853-882. Retrieved from https:// econpapers.repec.org/article/ mcbjmoncb/v_3a36_3ay_3a2004 _3ai_3a5_3ap_3a853-82.htm

32. Stiroh, K. J., \& Rumble, A. (2006). The dark side of diversification: The case of US financial holding companies. Journal of Banking \& Finance, 30(8), 2131-2161. https://doi.org/10.1016/j.jbankfin.2005.04.030

33. Sun, S. L., Peng, M. W., \& Tan, W. (2017). Institutional relatedness behind product diversification and international diversification. Asia-Pacific Journal of Management, 34(2), 339-366. https://doi.org/10.1007/ s10490-016-9498-4

34. Williams, B., \& Prather, L. (2010). Bank risk and return: the impact of bank non-interest income. International Journal of Managerial Finance, 6(3), 220-244. https://doi. org/10.1108/17439131011056233

35. Windmeijer, F. (2005). A finite sample correction for the variance of linear efficient twostep GMM estimators. Journal of Econometrics, 126(1), 25-51. https://doi.org/10.1016/j.jeconom.2004.02.005

36. Zhang, X., \& Daly, K. (2013). The Impact of Bank Specific and Macroeconomic Factors on China's Bank Performance. Global Economy and Finance Journal, 6(2), 1-25. 